This is a postprint (final submitted manuscript) version of the following article:

Parris, D., Troilo, M., Bouchet, A., \& Welty Peachey, J. (2014). Action sports athletes as entrepreneurs: Female professional wakeboarders, sponsorship, and branding. Sport Management Review. https://doi.org/10.1016/j.smr.2013.12.005 


\section{Action Sports Athletes as Entrepreneurs: Female Professional Wakeboarders, Sponsorship, and Branding Running Title: Action Sports Athletes as Entrepreneurs}

\section{Case study}

\section{Introduction}

Wakeboarding was perhaps the hottest action sport of the 1990s in the U.S. and was launched as a professional sport in 1992, when a Florida based sports promoter and event organizer, World Sports \& Marketing, began staging professional events. The sport is a cross between waterskiing and snowboarding, where one rides behind a boat and does tricks off the wake on the water such as spins and flips. It quickly grew in international appeal with contests being hosted around the world; however, Florida became and is still today the epicenter of the sport. If one wants to become a professional rider, Florida is the place to be. This is where the professional riders live, the top training schools are located, the weather enables year-round training, and one can access industry connections and build a brand. In the early days there was no professional women's division on the tour.

The first female entrepreneur in the sport was Andrea Gayton from Los Cabos, Mexico. Entrepreneurship involves the discovery, evaluation, and exploitation of opportunities to introduce new goods and services, ways of organizing, markets, processes, and raw materials through organizing efforts that previously had not existed (Shane \& Venkataraman, 2000; Venkataraman, 1997). Gayton trained and lived in Orlando, Florida on a lake with Scott Byerly, the legendary innovator of the sport, and began her professional career competing against the men. Her pioneering spirit enabled women to begin competing as professionals; however, 
professional status for women is not guaranteed. Female riders continually struggle to keep their place in professional wakeboarding.

The development of women's wakeboarding continues today as new pioneers like Amber Wing seek to push boundaries and establish themselves in a male-dominated industry. The World Wakeboard Association (WWA) professional ranking system exemplifies women's minority status in the sport. The WWA is the industry's organizing body created by wakeboarders, yet a women's division is not included in their rankings nor are there rules for how a woman might qualify to compete at the pro level (WWA, 2013). According to other ranking systems (World Wake, 2013) professional male wakeboarders outnumber the women three to one.

Amber Wing is continuing the entrepreneurial process begun by Andrea Gayton. Despite previous female riders attempting difficult maneuvers only executed successfully by the male riders Amber identified this as an opportunity to "lift the bar on awareness of female wakeboarding [by].... inspiring the women to be better, and in turn, inspire future generations of female wakeboarders." She became the first woman to land the difficult maneuvers known as heel-side 720 spin in 2006, a toe-side 900 spin in 2010, and a double back flip in 2013. In 2010 she spear headed a women only film project called 'Sets in Motion' produce in 2013 to motivate and push the women to progress their ridding even further. In wakeboarding women are not asked to get filmed or are not included in final film project whereas there are three to four film projects for male riders each year (Oakley, 2013). Her success is testimony to years of dedication and risk-taking. From ages two to 17 she spent her life at a gymnastic center and was a hopeful to represent Australia in the 2000 Olympics. A career-ending broken ankle cut short that dream. 
She found herself juggling a full-time job and part-time schooling while trying to redefine her identity as a professional wakeboarder.

Amber Wing found wakeboarding and it became her new passion. This paper provides interviews from female wakeboarders, identifying their struggle and a need for entrepreneurial activities for survival in the sport of wake boarding has permitted a teaching case to be developed. Similar to many riders, both international and U.S., Amber used her savings to travel to Orlando, Florida. She would work for six months at home to save money to go to Florida for six months for training and competition. As Amber recalls, "After three years I spent all my money and was thinking it was my last year. That make-or-break year for me ended with me coming home with money and contracts securing me financially for years to come." Her success encapsulated not only her tricks or style on the water, but also her business acumen off the water. Most professional wakeboarders represent themselves because agents are expensive. Being a professional wakeboarder is more than raw talent. It is vital for a rider to be an entrepreneur in building a unique personal brand, which is central to establishing sponsorships.

This is the first case to explore the sport of wakeboarding, specifically female professional wakeboarders. As highlighted by Wing, wakeboarding's niche popularity is reflected when a professional wakeboarder is asked, 'what do you do for a living?' The conversation usually turns in one of two directions: either the rider is enthusiastically recognized as a top professional in the sport, or the questioner grows confused and responds, 'What is a wakeboarder'? Thus, a person is either a fan of wakeboarding or has no knowledge about the sport. Wakeboarding's status as a minority sport leads to a gap in consumer awareness representing a challenge for sponsors, as well as athletes seeking sponsorship. Since the goal of sponsorship is to accelerate market awareness and acceptance, to stand out in the crowd (i.e., 
obtain differential advantage), cultivate interest and desire, and drive sales, minority sports, like wakeboarding, face the challenge of how to cut through the marketing clutter of mainstream sports. Additionally, elite female wakeboarders are a minority in a minority sport; they have to negotiate being female in a male-dominated actions sport industry. There is a fraternity mentality where the boys set the rules and decide who is in and who is out.

There are two primary objectives of this case. The first is for students to gain an understanding of the sport of wakeboarding by examining the experiences of elite female wakeboarders. The second is to challenge the readers of this case to address how female wakeboarders can benefit the sport and themselves via entrepreneurial activity. We begin by exploring the background and economics of action sports, the history of wakeboarding in the context of action sports, and then we review the branding, entrepreneurship, and sponsorship literature. Next, we present the experiences of elite female wakeboarders based on personal observations made by the first author, who is a past professional female wakeboarder, as well as personal interviews we conducted with 12 female wakeboarder professionals who were in various stages of their careers (six retired and six professional). There is very limited academic information on wakeboarding; therefore, the context of this case stems from the lived experiences of the female professional riders who were interviewed for this case, supported by industry publications (websites and magazines). Action sports, like wakeboarding, share their history among consumers through oral traditions, which are key to participation. This case highlights the cultural material and traditions of wakeboarding through the lens of elite female wakeboarders with careers spanning from 1990 to today. We discuss the challenges faced by female wakeboarders with regard to finances, sponsorship, self-branding, and the fraternity 
mentality. We conclude the case with study questions regarding the future of the women and the sport in light of these challenges.

The transition from amateur to professional does not necessarily depend on winning a professional tour, as all women interviewed for this case have won national, professional, and world titles while still working part-time jobs to cover expenses. Sponsors at first offer free equipment, and will pay entry fees to contests. Depending on the rider's success, sponsors may then cover travel expenses and offer bonuses for winning and photo incentives. The ultimate stage of earning a monthly or yearly income with a multi-year sponsorship contract remains a dream for most riders. In recent years the sport has faced stiff competition from other action sports such as skateboarding and snowboarding, with the majority of sponsors seeking to align with the sport that has the largest audience.

Entry of wakeboarding into the X Games in 1996, an annual competition of action sports managed by U.S. sport broadcaster ESPN, played a role in the rising status of the sport; however, it was dropped from the X Games in 2006. The significance of the lack of television exposure can be illustrated by a brief analysis of the viewership of the 2013 Winter X Games. In the U.S. alone, 35.4 million people watched televised events; online users spent a total of 8.1 million minutes on the X Games site; the X Games mobile app was downloaded 87,000 times, with over 2.5 million Facebook fans following the Games; and 108,000 fans attended in person (Transworld Business, 2012). There is a Catch-22: wakeboarding is not included in premier sporting events like the $\mathrm{X}$ Games or the Olympics due to a lack of following, but the following cannot be developed without inclusion in these events.

Women wishing to earn a living through wakeboarding have had to become entrepreneurs, both to land coveted sponsorships and to augment income from other sources such 
as coaching. These women also had to learn how to brand themselves, and to contend with gender inequities such as prize money being as much as four times higher for male wakeboarders than for females. Given these obstacles, does the sport of wakeboarding need to change its value proposition (See Exhibit 3)? What could female riders do that would advance both the sport and their own careers? These are the salient questions wakeboarding and its female participants face.

\section{Entrepreneurship, branding, and sponsorship}

Professional wakeboarders are entrepreneurs who provide a service (entertainment) while building their own brands in a market niche that is virtually brand new (action sports). In a more traditional interpretation of entrepreneurial activity, they are self-employed. Also, in the world of action sports the brand is the individual. O’Malley (1991) defines a brand as a "name, symbol, design, or some combination which identifies the product of a particular organization as having a substantial, differentiated advantage" (p. 107). The product a wakeboarder sales to corporate sponsors is herself or himself. One clear driver of successful self-branding is successful riding. For example, Dallas Friday has received Rider's Choice Award by WakeWorld, a media website devoted to wakeboarding, as one of the top female riders in 2010, 2011, and 2012 based upon a ballot taken by other pro riders as well as fans (Exhibit 1). She has parlayed that success into a number of corporate sponsorships (Exhibit 2).

Sponsorship is defined as "an investment, in cash or in kind, in an activity, in return for the exploitable commercial potential associated with that activity" (Meenaghan, 1991, p. 36). As such, perhaps there is a relationship between the sponsoring company and the athlete in action sports that does not exist in other sports. These individual sponsorships also allow companies to enter into branding opportunities that do not exist in team sports, which require separate agreements between the company, team, individual player, and possibly the player's association. 
The benefits of action sport sponsorships are that they allow marketers to cut through the clutter of traditional marketing (radio, television), reach targeted audiences, and enable the company to differentiate a brand from its competitors (Rooney, 1995). For instance, one of action sport snowboarder Shaun White's main sponsors is Target. Target, a discount retailer based in Minneapolis, Minnesota (U.S.), uses its sponsorship with White to brand a line of clothes geared toward boys and young men. By establishing separation from competitors, companies gain pricing power. They can charge a premium, based on the perception, if not the reality, that their product or service is better than that of their rivals.

The world of wakeboarding hinges upon the effective combination of entrepreneurship, branding, and sponsorship (Exhibit 3). These efforts start with the wakeboarders themselves, who strive to innovate their routines and create exciting new moves for the public to consume. The entrepreneurial activities of the athletes continue with self-branding and promotion, which will further enhance the brands of their sponsors, leading to more sales to the public. Synergies among these components serve to propel the entire domain of wakeboarding.

\subsection{Background and economics of action sports}

Action sports involve pushing the boundaries, defying conventional rules, and placing oneself at risk or danger to do what others have never done in the air, land, or water. Action sports athletes seek to define their own terms by challenging established norms, defying laws of gravity, and contesting the numerous environmental variables of Mother Nature. The birth of the action sport industry was started by entrepreneurial hobbyist who sought to build innovation solutions to the limits of established sports (Parris, 2013). For example, a wakeboard allowed riders the ability to do maneuvers on the water never attempted previously due to the limits of the equipment. One of the key attributes of action sports is their focus on the individual 
(Wheaton, 2004). The counter-culture of action sports values creativity and individualistic qualities, provides a space for individual expression, and embodies the image of 'cool' by fostering entrepreneurism. The status of 'cool' is established through 'innovation, freedom, rebellion, self-expression, and breaking established norms" (Parris, 2013, p. 142). Increasingly, these sports are being accepted by both network television and consumer product companies willing to spend sponsorship dollars to reach target demographics. This acceptance has led to significant sponsorship dollars being spent on the professional athletes in these sports.

From an economic viewpoint there are distinct differences between traditional professional sports and action sports. These differences are rooted in the length of time these sports have been established, the manner of establishment (e.g., franchising), the fan base they have developed, and the revenue streams they consequently earn. Action sports do not have the undergirding infrastructure that professional team sports and more traditional individual sports enjoy precisely because action sports are so new. Teams in traditional professional sports leagues rely on broadcasting revenue, ticket sales, and merchandising to support their payroll. The four major professional sports leagues in North America, or the "Big Four" (National Football League, National Basketball Association, Major League Baseball, and the National Hockey League) have franchises in every market in the U.S. and Canada with a population above 1,000,000 (2010 U.S. Census; 2011 Canada Census). These franchises often hold a monopoly or a duopoly (e.g., the New York Giants and New York Jets in American football in the New York City metropolitan area).

Individual athletes in sports such as golf and tennis do not have the same clout as franchises in the "Big Four"; however, they are still in a sporting realm far more established than action sports. Professional tennis, golf, car racing, and skating associations have existed since the 
late $19^{\text {th }}$ or early $20^{\text {th }}$ Century ${ }^{1}$. This length of establishment equates to significant sponsorship dollars from the corporate sector and participation in "leagues" (e.g., Professional Golf Association) or tournaments (e.g., Wimbledon). According to Forbes (June, 2012) seven of the of top 10 highest paid female athletes are tennis players ranging from Li Na earning USD \$18.4 million per year (seven, three-year multimillion dollar endorsement deals with Mercedes-Benz, Samsung Electronics, and several Chinese firms) to Agnieszka Radwanska earning USD \$6.9 million per year (major sponsors include Lotto, Babolat, and Lexus). Other top earners are NASCAR driver Danica Patrick (USD \$13 million), Olympic ice skater Kim Yu-Na (USD \$9 million), and five-time Major winning golfer Yani Tseng (USD \$6.1 million).

As wakeboarding is among the newer of action sports, professional riders must be even more enterprising in order to make a living out of their passion. In contrast to the female athletes' earnings mentioned above, the payoffs for action sports are far less lucrative than for either tennis or golf, as action sports are much more recent in origin and have a smaller market. Action sports professionals must rely on sponsorships to finance their careers, and as a result, a premium is placed on the entrepreneurial spirit of these individuals.

For example, in the sport of snowboarding, an Olympic sport since 1998, the top-earning athletes of the 2010 Winter Olympics in Vancouver were male snowboarder Shawn White (USD \$7.4 million in sponsorship dollars), while the top three female snowboarders (Gretchen Bleiler, Lindsey Jacobellis, and Hannah Teter) earned an estimated USD\$1 million each (Forbes, 2010). In contrast to snowboarding, wakeboarding is not an Olympic sport, and was only in the X Games from 1996 to 2006, which has resulted in less media attention causing potential sponsors to seek other sports. Although female wakeboarders compete in tournaments, the prize

\footnotetext{
${ }^{1}$ For example, the United States Tennis Association (USTA) dates to 1881 and the Professional Golfers Association (PGA) was founded in 1929.
} 
money is low, with the title sponsor only providing the first place winner a sum of USD $\$ 2,000$.

Thus, female riders have to depend largely on sponsorship contracts to earn a living at wakeboarding. Based upon the interviews conducted for this case study, their earnings range from USD $\$ 25,000$ to $\$ 100,000$ per year. All of these athletes rely on sponsorship money to offset tournament entrance fees, training, and travel; hence, self-branding and promotion are essential.

\subsection{History of wakeboarding in the context of action sports}

The majority of action sport companies emerged as sport enthusiasts (hobbyists) brought their creativity to market; they innovated and stretched the boundaries of existing sports (Shah, 2004). According to USA Waterski (2013) and the female riders interviewed for this case study, wakeboarding emerged in the late 1980s after the advent of ski-boarding, which is now known as snowboarding. Similar to a snowboard, the original wakeboard or "skurfer" was developed in 1985 by a surfer named Tony Finn. The skurfer was a one-directional board resembling a cross between a water ski and a surfboard. Herb O’Brien (1944-2012), owner of leading water ski manufacturer H.O. Sports, changed the wakeboard industry by introducing a "twin-tip" design. This symmetrical shape board with fins on both ends enabled equal performance whether the wakeboarder rode forward or in the switch-stance position (switch-stance is riding the board backwards from one's normal riding stance). O'Brien's first wakeboard was also the initial neutral buoyancy board. This innovation enabled easy deepwater starts, making wakeboarding accessible to boaters around the world.

Wakeboarding was one of the biggest sports-related phenomena of the past decade and was considered the fastest-growing water sport with nearly four million enthusiasts across the globe (USA Waterski, 2013). Significant time markers in the growth of the sport, according to 
the first author, the female riders interviewed for this case study, and various industry organization websites (USA Waterki, 2013; WWA, 2013; ESPN, 2013) include:

a) World Wakeboard Association (WWA) was founded in 1990;

b) Wakeboarding became part of the Professional Water Ski Tour in 1992;

c) Wake Boarding magazine was launched in 1993;

d) 1996 ESPN X Games showcased wakeboarding to millions of viewers across the world;

e) In 1998 both the Vans Triple Crown (a series of three individual events with an overall champion each year), and the World Cup (a series of events hosted across the world in Indonesia, Japan, and Australia), were created; and

f) The sport diversified in 2000 by adding rails, sliders, and kickers (obstacles generally made of metal, PVC, or wood used as an object to slide on or as a ramp by a wakeboarder) to professional competitions.

Female riders interviewed cited two major events in the early 2000's that continue to impact wakeboarding today. The first was the introduction of wakeskating. As the name suggests, this is a combination of wakeboarding and skateboarding. The board has no bindings, is smaller, and is covered with grip tape on the top, like a skateboard. The second was the addition of Junior Men to the Professional Wakeboard Tour. Coincident with these developments, women were only invited to two of the five professional tour events. Women were told to seek their own sponsorships if they wanted to continue to be represented at all five tour stops. To date, the women still remain on only two professional tour stops.

The growth of wakeboarding seemed unstoppable until competition from other action sports like snowboarding, skateboarding, and surfing attracted the attention of major brands 
(Nike, Vans, RedBull, Oakley, Coca-Cola, AT\&T) seeking sponsorship opportunities. Thus, sponsorship for large wakeboarding events declined with this shift in focus. In addition, 2004 marked wakeboarding's last appearance in the Vans Triple Crown, and 2006 marked the last year of wakeboarding at the X-Games. The reasons X-games provided for no longer including wake boarding in the event were the difficulty and expense of locating a facility (a lake) that was easily accessible from other venues, and the lack of support for and investment in the wakeboarding industry itself. In addition to being limited to only two of the five professional tour stops and losing two other major events (Vans Triple Crown and X Games), other opportunities for female wakeboarders to gain exposure for their sponsors and earn a living as professionals in the sport continued to decline.

The economic downturn in the U.S. shortly followed these initial struggles. Increased fuel prices and the rising cost of boats and equipment further diminished the sport, and both sponsors and athletes dropped out due to finances. Also, competitive wakeboarding needs sponsorship to be profitable. Major brand names willing to host large-scale competitions, and support from the boating industry and from venues in major cities, is essential. Without this assistance, the cost of competing professionally is overwhelming to most individuals. The economics create a classic paradox; sponsors will only back competitions if the popularity of wakeboarding justifies the expense, but wakeboarding can only become popular by holding competitions. The declining number of competitions has made it more difficult to raise sponsorship dollars, leaving male and female professional wakeboarders struggling to make a living in what was once the fastest growing watersport in the world for a decade.

\section{Challenges of being a Female Rider}

\subsection{Financial pressures}


The female wakeboarders interviewed for this case are entrepreneurs who capitalized on their talent and passion for the sport, along with their creativity and business skills, to transform wakeboarding into a career. In the transition stage from amateur to professional, the age of entry determined the means of support. Those who started the sport in their late teenage years or in their early 20's mainly paid their own way, whereas the women who started between the ages of 10 and 15 had the backing of their family. Primary influences on financial concerns included family resources, whether the athlete attended college while competing, where the athlete lived, the overall context of wakeboarding (e.g., growth vs. decline), and the athlete's ability to create ways to earn income from the sport. If the definition of being a professional wakeboarder, as one rider described, "is when you are doing it for your job . . you are getting paid to wakeboard," then all of the women interviewed for this case fit this description for at least two years of their careers. However, it is important to acknowledge that earning and maintaining an income from the sport has been a challenge for the majority of women. Many have become increasingly entrepreneurial to realize their dream of being a professional wakeboarder.

For the majority of professional female wakeboarders on their first year of the professional tour (i.e., circuit of professional contests/events), they or their parents pay expenses such as flights, hotel rooms, and entry fees. Several women told stories of flying to events where family members lived or going to a professional tour close to home to compete in their first event. Many simply entered their first event to explore if they were good enough to compete against the top women in the world. Earning an income from the sport for many women did not occur until several years after competing at the professional level, as one current professional explained: "During my transition from amateur to pro I lived off my savings that I had saved ... over 20 years ... however that went into my career." Most of the women told stories of doing 
everything they could to scrape up enough money to purchase fuel to go ride, such as working as waitresses, grocery store clerks, and sales associates at their local action sports shop. Several international riders came to the U.S. and worked as coaches or cooks at wakeboard schools in exchange for room, board, and time on the water. None of these jobs created enough revenue to build savings or do anything other than work towards their dream of becoming a professional rider. Early in their careers, every dollar the women earned went towards the sport, and for some even when they did earn money from wakeboarding, it went straight back into riding.

A professional rider's income needs to be sufficient to cover the following items: cost of living (includes groceries, housing, utilities, transportation, and health care); a wakeboard boat (USD \$30,000 for a used boat to USD \$85,000 for a new one, plus insurance, taxes and registration fees), with only a few top ranked professionals provided a boat by a boat company that they have to give back at the end of season; boat maintenance (engine, interior, exterior); boat fuel ( three sets/rides a day, five gallons of fuel per set, five days a week, average fuel price USD \$3.5 per gallon equals approximately USD \$265.5 per week); a vehicle to tow the boat plus fuel for it; and, a place to store the boat, ideally on the water for easy daily access. In addition, the women have the costs associated with taking care of one's body (gym membership, weekly massages, yoga classes), and getting coached both on and off the water (trampoline training and personal trainers). All the above do not take into account building one's brand through websites and social media or earning enough to have a savings for financial emergencies, time off the water due to injuries, or the future.

\subsection{Sponsorship}

There is no guidebook on how to become a professional wakeboarder, nor is there a tiered development model as found in traditional sports, according to the female riders 
interviewed. In addition, there is generally not enough sponsorship money in the industry for women to earn an income beyond money needed for covering living, training, and travel expenses required to participate in the sport. There are no sports agents due to the limited amount of sponsorship dollars within the industry, and in addition, there is an absence of companies outside of the industry who are willing to invest in the sport.

There are only a few women who compete on the professional tour whom wakeboard companies select to be on their professional team comprised almost exclusively of male wakeboarders; some of the women referred to it as being the "token" female on the team. One professional rider confirmed this when she said "it seems there are a few girls who get a lot of attention and are at the very top ... when there are only three girls that people want to sponsor it keeps hurting the other girls." The female wakeboarders generally found their own sponsors, negotiated their own contracts, and thought creatively about how they could make a living from wakeboarding to support their passion and what some called their "addiction" to the sport. One retired rider offered this advice to young women considering becoming professional wakeboarders:

Do it because you love it, not because you plan on making money at it. Enjoy every moment of it because do not expect ... [that] you are going to make millions ... do it because you love it because that's the only way you are going to survive in this industry. It's about a passion thing ... . it has to be.

Passion is a hallmark of entrepreneurs, but it alone is not enough for success. There also has to be a capacity for recognizing opportunities. The female riders recognized this, and were adaptable in lean circumstances. Earning sponsorship dollars is critical for female professional wakeboarders to compete at the highest level and remain on the tour. For some women gaining 
sponsorships was a battle, so they sought alternative ways to make a living from the sport such as coaching, serving as commissioned sales representatives, becoming a member of product design teams, modeling, and serving as consumer insight consultants. In this exploitation of opportunities they were entrepreneurial. Only a few obtained sponsorship contracts that provided enough income to earn a living from the sport for several years or more. One retired rider described the importance of sponsorship:

It comes down to money ... If your sponsors are helping you out . . you do not have to work another job ... [or] worry about how [am I] going to pay the bills ... or eat this week ... or get my body fixed after I beat it up.

Sponsorship dollars allow athletes to give $100 \%$ of their ability and energy to the sport. Without sponsorships, many of the women spoke about the physical and mental pressures of managing both their wakeboarding job and their second job, a necessity to support their passion and their first job.

Being a professional wakeboarder necessitates attendance at competitions on the tour; as discussed in the preceding section, travel costs are a prominent operating expense (e.g., plane tickets, entry fees, hotels, food, and other miscellaneous expenses). As a professional rider travels with equipment on an airline there are additional challenges, such as the risk one's gear will not arrive in one piece, and the challenges of traveling with anything other than a standard "golf bag." Sponsorship defrays these costs, which otherwise quickly exhaust individual savings. One retired athlete, who turned professional before she was 18 , spoke about the need for sponsorship dollars, saying that "the pressure was on me; if I wanted to do this, I needed to be in the top five ... so [Company X] would pay for me.” A current professional rider illustrated that this has not changed when she described the role sponsorship dollars played for her: 
It used to make me really nervous when I didn't have enough . . . to go to . . . [a] contest ... I had several sponsors who were willing to give me money, but they just also gave me a lot more pressure at the same time [and they] gave me the cold shoulder when I didn't do well at contests.

Sponsorship money is critical to be able to afford to go to tournaments. Not only is prize money not guaranteed, it has decreased over the years for both men and women. Female wakeboarders noted the women's top podium position on the 2010 professional tour earned USD $\$ 2,000$, which is enough to cover travel costs only. To earn a living through sponsorships, a professional wakeboarder needs to cover costs beyond receiving product (equipment) and travel dollars. A female rider who has successfully secured sponsorship contracts that have given her the ability to make a living from the sport for years stated a basic contract should have a "loyalty agreement, contract of salary, endorsements, and royalties if your name is on the product."

Andrea Gayton's initial contract with wakeboard manufacturer Fulltilt serves as an example. Gayton was the first woman to have her own professional model wakeboard, the Supermodel. Her contract specified the following: she promised to only ride that board (loyalty agreement by rider); the company promised not to sponsor another female without her approval and the option to re-negotiate her contract (loyalty agreement by sponsor); contract of salary monthly payments plus photo and winning incentives; additional financial incentives for endorsements of products, personal appearances, and video shoots; and, royalties from her professional board model (i.e., a percentage of gross or next revenues derived from the sale of the board). Every female rider interviewed stressed that professional wakeboarding women represent themselves and are responsible for negotiating their own contracts. This can be overwhelming in a male-dominated industry. 
The income of female professionals varies throughout their careers. One female rider was told by a top wakeboarding company that "the top guy makes 100 grand [and] a top girl makes 25 ; that is a really good salary compared to a minimum wage salary when you look at it." However, a minimum wage salary does not cover the necessary costs of a boat nor leave enough for savings. One current professional female rider pointed out that "it is a lot harder for girls right now to get into the sport because there is just not a whole lot of money out there to support them, their career, and what they want to do." Some of the women interviewed were lucky and entered the sport at the peak; however, all of the women at some point in their professional wakeboarding career struggled financially to stay on the professional tour.

Several of the women, who did not have monthly salaries from sponsorship dollars either throughout their entire career or at a phase of their career, took a different route to earning a living in the sport. As one highlighted, "there are all kinds of ways to support and grow your name in the sport. ... [such as] making sponsor videos, doing plug-ins, the Internet, boat shows, clinics, and coaching." Many of the women were able to secure a sponsorship deal that provided a boat to use each year, as one rider, who promoted herself as a saleswoman, stated:

I felt lucky because I was able to get a boat . . . there were not a lot of people getting boats ... I may not have a pay check coming in but ... I needed something to ride behind ... I was more than just a rider. I could sell [the company's] equipment . . . I was great with families and the boat. So, I tried to sell myself on that angle.

\subsection{Self-branding and promotion}

Due to the limited number of opportunities for female wakeboarders to gain exposure through media and contests, many of the riders, as highlighted by a current professional rider, found that "it is up to you [the female rider] to come up with ways to help promote them [your 
sponsors]." In this, the wakeboarders had to recognize and exploit opportunities to create value just as more traditional entrepreneurs do. As stated previously, many of the women made a living in the sport as promoters of the sport through coaching clinics, boat shows, and doing road tours across the nation.

An important part of being a professional wakeboarder is defining and creating your own brand name in the industry. For example, an athlete can market herself as the woman who is on top of the podium every weekend or the woman who is the best coach in the industry. As one retired professional, who marketed herself as product expert for her sponsors, stated, "I would go to boat dealers and teach them about the boat, how to drive ... how to do comparison sales ... I was actually an educational freaking guru." It is important to note most of these women hosted and organized coaching clinics on their own initiative using business acumen learned mainly through experience along with their pure determination to find a way to make a living in the sport.

All of the women interviewed for this case became more than wakeboarders in the course of their careers as female professional riders. As one current professional rider testified, "wakeboarding is such a small sport; you are the promoter, the athlete, the marketer and the manager." This same rider spoke about the pressures of having to be everything at once; "juggling marketing yourself, staying healthy, and being at all events is physically, mentally, emotionally challenging. It is a balancing act to promote and build your name as a brand.” The first author can personally attest to this. As a past professional wakeboarder herself and after doing an Olympic campaign in windsurfing, she discovered that one of the most difficult challenges is having multiple jobs all at once and still finding both the time and the energy to train to be a top athlete. 
Without agents the women are responsible for marketing themselves, finding their own sponsors, and negotiating their own contracts. One current professional rider's advice to young females entering the sport illustrated the essential role and absolute need for women wanting to earn a living in the sport to be able to market themselves; "keep practicing and practicing ... market yourself ... learn a few skills such as video editing and photography ... on your own... [Do] not wait until someone comes to you but really make it happen yourself." Another professional rider emphasized the importance of women taking initiative:

New girls don't know the routine like if they learn a new trick they don't go 'hey let's go shoot' . . a and I know when I learn a new trick I call my buddy ... or whoever and have them come shoot ... rather than waiting for sponsors to set up something you got to call in. You know compared to some of the guys who live with a photographer and film every single day.

This comment reflects the need for women to take initiative. It also intimates that there is an ingroup and an out-group within the wakeboarding industry.

\subsection{Fraternity mentality}

The wakeboard industry, similar to other action sports, is a fraternity where men have the advantage of being in the "in-group" and have the connections to get photos in magazines. According to the interviewees, the wakeboarding industry is run by men. A professional female rider observed the challenge of seeking sponsorships in an industry dominated by males, stating that the sport "is mostly run by men ... it can kind of be intimidating sometimes to talk to different team managers ... different sponsors that are all men. So ... you have to be more outgoing and make it happen." Another professional female rider agreed that the relationships with sponsors in the industry are different for men and women; "if the team manager is a man 
then the boys all 'bro down' [males form fraternity 'boys only' bonds] creating better relationships between them and the company. I keep a very professional relationship with companies. I deal with it [the boys club] . . this works for me.” Even though the fraternity structure of the wakeboarding industry creates potential barriers for female professional riders, none of the women let these barriers stop them.

In the 18 years Wakeboarding the magazine has been published monthly, it is extremely rare for a female professional rider to be featured on the cover, with the interviewees only recalling this occurrence less than five times. Generally, in each issue there is only one photo of a woman riding, with all other women in the magazine being shown in thong bikinis, topless, or in a suggestive sexual pose. Several of the professional women have taken the initiative to create their own online magazine for female action sports athletes called Mahfia.com. Many women maintain their own websites and market themselves through social media. When it comes to figuring out how to earn a living in the sport, all of the interviewees shared the same "go for it" attitude, exemplified by one professional rider's assertion: “you can be as big as you want ... it is just about your outlook and how you go about it." All female riders told stories of creating portfolios and videos to market themselves to sponsors, using social media to build a fan base, and representing themselves as role models to other women. Common advice to up-and-coming female riders was to be wholesome, as illustrated by this comment:

You need to make sure to keep good behavior ... stay a good girl and . . . a good role model for other little girls ... have a good attitude and being welcoming to people who are new to the sport is a really good trait to have if you want to become a professional wakeboarder. 
Passion alone does not suffice; determination is also critical. All of the professional female riders spoken with became entrepreneurs pursing their passion to become a professional wakeboarder. Despite obstacles, they maintained an attitude that girls can do it, too.

\section{Conclusion}

Professional female wakeboarders face a murky future. The value cycle that sustained wakeboarding in the golden years of the 1990s (Exhibit 3) is currently dysfunctional. What can the sport do to revive its fortunes? Does the industry need an entirely new model, or can it repair the old one? What can the individual women riders do to help the sport as they help themselves?

Amber Wing's goal is to raise the bar on awareness of women's wakeboarding. During the writing of this case she has led the creation of a women's wakeboard film series released online in episodes as teasers to the full-length online film called Sets in Motion (Oakely, 2013). Can the use of multimedia help change the value proposition wakeboarding, specifically female riders? As an entrepreneur how would you raise the status of wakeboarding?

\section{References}

Dallas Friday website. Accessed on June 20, 2012 at http://www.dallasfriday.com

ESPN (2013) website accessed on February 26, 2013 at http://espn.go.com

Forbes (February, 9, 2010). Top-earning athletes of the 2010 Winter Olympics. Accessed on

February, 25, 2013 at http://www.forbes.com

Forbes (July, 30, 2012). Olympic starts top the list of the 10 highest-paid female athletes.

Website accessed on February, 25, 2013 at http://www.forbes.com

Meenaghan, T. (2001). Understanding sponsorship effects. Psychology \& Marketing, 18(2), 95-122.

Oakley website accessed on August, 4, 2013 http://www.oakley.com 
O’Malley, D. (1991). Brand means business. Accountancy, 107, 107-108.

Parris, D. (2013). Conceptually meeting expectations of Generation Y by building personalized customised hybrid bundles to target action sports consumers. International Journal Revenue Management, 7(2), 138-154.

Rooney, J. (1995). Branding: a trend for today and tomorrow. Journal of Product \& Brand Management, 4, 48-55.

Shah, K. (2004). From innovation to firm formation in the windsurfing, skateboarding, and snowboarding industries. University of Illinois Working Paper, 05-0107.

Shane, S. (2003). A general theory of entrepreneurship, Northampton: Edward Elgar Press.

Shane, S., \& Venkataraman, S. (2000). The promise of entrepreneurship as a field of research. Academy of Management Review, 26(1), 13-17.

Transworld Business (2012). X Games 2012 Rating Soar. Website accessed on February 26, 2013 at http://business.transworld.net

USA Waterski website assessed on February, 26, 2013 http://www.usawaterski.org/

Venkataram, S. (1997). The distinctive domain of entrepreneurship research: An editor's perspective. In J. Katz \& R. Brockhaus (Eds.), Advances in Entrepreneurship, Firm Emergence and Growth, 3, (pp. 119-138). Greenwich, CT: JAI Press.

Wakeworld website, accessed on June 20, 2012 http://www.wakeworld.com/news/feature/2011-wakeworld-riders-choice-awards.html http://www.wakeworld.com/news/feature/2010-wakeworld-riders-choice-awards.html?page=3

Wakeworld website, accessed on August 1, 2013 http://www.wakeworld.com/news/latestinwake/2013-pro-wakeboard-tour-standings.html

Wheaton, B. (2004). Mapping the lifestyle sport-scape. In B. Wheaton (Ed.), Understanding lifestyle sport: Consumption, identity and difference, (pp. 1-28). Abingdon: Routledge World. 
Wakeboard Association (WWA) Website, accessed on June 20, 2012 http://www.thewwa.com/queen-of-wake/

Exhibit 1: WakeWorld Rider's Choice Awards top Female Riders of 2012- 2010 2012

1. Dallas Friday

2. Nicola Butler

3. Amber Wing

4. Meagan Ethell

5. Melissa Marquardt

2011

1. Amber Wing

2. Nicola Butler

3. Dallas Friday

4. Emily Durham

5. Melissa Marquardt 
1. Amber Wing

2. Dallas Friday

3. Nicola Butler

4. Emily Durham

5. Melissa Marquardt

Source: Wakeworld website, accessed June 20, 2012 and accessed August 5, 2013 http://www.wakeworld.com/news/feature/2011-wakeworld-riders-choice-awards.html http://www.wakeworld.com/news/feature/2010-wakeworld-riders-choice-awards.html?page=3

\section{Exhibit 2: Sponsors of Dallas Friday}

O’Brien International Watersports http://www.obrien.com/

Malibu Boats http://www.malibuboats.com/

Fox Riders Co. http://www.foxhead.com/us/

JBL http://www.jbl.com/

Red Bull http://www.redbullusa.com/cs/Satellite/en_US/Red-Bull-Home/001242746208542

Performance Ski \& Surf http://www.perfski.com/

Orlando Watersports Complex http://www.orlandowatersports.com/

AKG http://www.akg.com/

Honu Footwear http://teamhonu.com/ 




Source: Dallas Friday website accessed on June 20, 2012 at http://www.dallasfriday.com/sponsors.html

Exhibit 3: Cycle of value in the women's wakeboarding industry

Public

-Watch competitions

-Buy merchandise 
Source: The authors

\section{Action Sports Athletes as Entrepreneurs: Female Professional Wakeboarders, Sponsorship, and Branding \\ Teaching Note}

1. Synopsis

“Action Sports Athletes as Entrepreneurs: Female Professional Wakeboarders, Sponsorship, and Branding" concerns itself with the sport of wakeboarding and how its female practitioners need to be entrepreneurial in order to make a living from the sport. This teaching note provides the pedagogy, theoretical underpinnings, and methodology behind the case, 
whereas the case itself is written in a more approachable manner to grab and hold the attention of the students.

The introduction to the case highlights the broad trend of the sport over the past two decades: phenomenal growth followed by a steady decline as other action sports took market share. It gives the perspective of a female wakeboarder, or "rider", who must seemingly be in constant motion in order for her passion to provide an income. The introduction then proceeds to outline the economic distinctions of action sports and to discuss the history of wakeboarding in the context of action sports before closing with the current difficulties besetting wakeboarding.

From the introduction to the core of the case there is a "bridge" section illuminating the confluence of entrepreneurship, sponsorship, and branding. The key point here is how synergies among these three activities create value in the industry (Exhibit 3 in the case). The overarching question for discussion is how to revive the fortunes of the sport.

The third section is the crux. Students ponder the financial pressures of becoming a professional female wakeboarder, and how to sustain momentum once one turns professional. The significance and inter-relationship of sponsorship and self-branding/promotion figure prominently in this portion of the case. The costs of competing are high in the best of circumstances, and nearly insurmountable without corporate backing. Obtaining such support requires a healthy degree of marketing oneself. The female riders offer a number of anecdotes and recollections surrounding these concerns; their importance is clear. Overshadowing both sponsorship and self-branding, and by extension the financial pressures, are gender issues. Male riders may earn up to four times more than what female riders receive on the tour, and there is pressure to adapt to the "boys' club" to advance one's career. Earning a living by riding is difficult for both men and women, but more so for the latter. 
The case concludes with the most salient questions facing the sport and its participants. What can the female riders do to help wakeboarding while helping themselves? Does the value proposition of wakeboarding (Exhibit 3 in the case) need a complete overhaul, or just some tinkering?

\section{Teaching objectives}

We wrote the case for undergraduate and graduate students in sport management, entrepreneurship, and marketing. The major themes of the case include entrepreneurial activity, branding, gender inequality, and industry analysis. A robust discussion of these themes should lead students to see that there are no easy alternatives for either the women riders individually or wakeboarding as a whole to improve the situation. In the near term, any advances are likely to be incremental.

\section{Study questions}

In this section we provide the major study questions for the students to prepare. We then offer ancillary questions by theme to help the instructor direct the discussion. The major study questions also appear in bold by theme for the sake of convenience.

1. Are wakeboarders entrepreneurs? Why or why not?

2. Examine Dallas Friday's sponsors in Exhibit 2. Look up the websites provided. How would you characterize these sponsors? What market(s)/demographics do they target?

3. Describe the various ways female riders might create their own brand. What do you think would be an effective way to self-brand in this industry? How might technology, specifically social media, help in this process? 
4. Regarding gender issues, to what extent should female riders cooperate with the status quo, and to what extent should they challenge it? How much leverage do the female riders have?

5. What can wakeboarding do to revive its fortunes? Does the sport require a new business model, or is it sufficient to revive the old one?

6. How can individual riders help the sport as they help themselves?

\section{Teaching plan}

We anticipate the case discussion filling a 75-minute class and covering the six sections listed below.

\subsection{Introduction (5 minutes)}

Before moving directly into the assigned questions, the instructor may wish to engage the class with questions such as:

- What are your impressions of action sports in general? Of wakeboarding in particular?

- How do action sports differ from other sports?

The purpose behind these questions is to gauge the students' familiarity with the topic: what have they seen and heard to this point from various media sources? The case discusses the differences between wakeboarding and other sports. In action sports like wakeboarding, the focus is on the individual, as opposed to team sports like basketball. Other individual sports, like golf and tennis, have much longer histories than action sports. As a consequence, they also have much larger markets and paychecks for their athletes.

\subsection{Entrepreneurship (15 minutes)}


Discussing the economics of action sports vs. "traditional" sports may lead naturally into the first main area of the case: entrepreneurship. The instructor may say, "We've been comparing action sports athletes to those in more traditional sports. The case tells us that the former often need to be entrepreneurial in order to earn income.

\section{- Do you think wakeboarders are entrepreneurs?"}

This question obviously is germane to the case. A more generic question is:

- Who is an entrepreneur?

If the case is being used in an entrepreneurship class, then the students are already likely familiar with some basic theories of entrepreneurs and entrepreneurship. Schumpeter (1934) defined entrepreneurship in terms of innovation. Entrepreneurship involves radical change and demands novelty and creation, either bringing an entirely new market into existence or enhancing an existing market in a significant way. As such, these types of opportunities are rare, and when they occur their effects are dis-equilibrating on current markets and perhaps even on society (Troilo, 2010; Shane, 2003). This concept of dis-equilibration is the basis of "creative destruction", whereby capitalism renews itself as new innovations and businesses demolish the old (Schumpeter, 1942). The entrepreneur as innovator/empire-builder is the popular view; witness the worldwide fascination with Steve Jobs and Bill Gates.

It should be pointed out during the conversation, however, that this kind of entrepreneur is quite rare. Far more common is the Kirznerian $(1973 ; 1997)$ model, which casts the entrepreneur as a discoverer of opportunities. Any innovation is incremental in nature; the entrepreneur functions to bring markets into equilibrium via arbitrage and speculation (Troilo, 2010; Shane, 2003). Differentiation from existing competitors is minor, and there is no radical shift in the industry. 
Still other facets of entrepreneurship may emerge. Students may focus upon an entrepreneur as a bearer of risk (Knight, 1921) ${ }^{2}$. They may differentiate between those who are self-employed vs. those who employ others (Shane, 2003), where they may consider the latter to be entrepreneurs and the former not to be. They may also point to circumstances, saying that an entrepreneur chooses to be so and is not someone who merely ekes out a living because she has no other choice (Storey, 1994). If students have not been exposed to these ideas, the instructor might record student opinions (e.g., "innovator", "bears risk") where the class can see them, and then introduce the relevant theories of entrepreneurship as the discussion unfolds.

The case offers a broad definition; entrepreneurship involves the discovery, evaluation, and exploitation of opportunities to introduce new goods and services, ways of organizing, markets, processes, and raw materials through organizing efforts that previously had not existed (Shane \& Venkataraman, 2000; Venkataraman, 1997). It then makes the claim that wakeboarders are "entrepreneurs providing a service (entertainment)." Instructors should probe to see the extent to which students are skeptical of this assertion. The point is to encourage students to construct sound arguments, not to compel them to adopt any orthodoxy. The truth of the matter is that scholars have not settled on what constitutes an authentic entrepreneur. It is also important to note that not all of the different ideas of entrepreneurship are mutually exclusive; a risk-bearer might also well be an innovator. Table 1 summarizes these concepts.

\section{Table 1. Concepts of entrepreneurs/entrepreneurship}

\begin{tabular}{|l|l|l|}
\hline Concept & Originator & Explanation \\
\hline $\begin{array}{l}\text { Entrepreneur as innovator, empire- } \\
\text { builder }\end{array}$ & Schumpeter $(1934,1942)$ & $\begin{array}{l}\text { Entrepreneurs are larger-than-life, } \\
\text { creative, and revolutionary. }\end{array}$ \\
\hline Entrepreneur as discoverer & Kirzner $(1973,1997)$ & $\begin{array}{l}\text { Entrepreneurs find opportunities } \\
\text { that previously did not exist. They }\end{array}$ \\
\hline
\end{tabular}

${ }^{2}$ Suffice to say that Knight's ideas concerning risk and uncertainty spawned an enormous literature in economics and finance concerning what precisely he meant by these terms and what the implications are. It will probably help the conversation to allow students to use "risk" and "uncertainty" interchangeably, as in the vernacular. 


\begin{tabular}{|l|l|l|}
\hline Entrepreneur as risk-bearer & Knight (1921) & $\begin{array}{l}\text { make markets by bringing buyers } \\
\text { and sellers together. }\end{array}$ \\
\hline $\begin{array}{l}\text { Entrepreneur as employer vs. } \\
\text { entrepreneur as self-employed }\end{array}$ & $\begin{array}{l}\text { Entrepreneurs are able and willing } \\
\text { to shoulder more risk than others } \\
\text { because they are better equipped to } \\
\text { assess the probabilities of uncertain } \\
\text { events. }\end{array}$ \\
\hline $\begin{array}{l}\text { Entrepreneur as willing vs. } \\
\text { entrepreneur having no other option }\end{array}$ & Shane (2003) & $\begin{array}{l}\text { Shane (2003) incorporates both in } \\
\text { his definition during an exhaustive } \\
\text { review of the literature. Some } \\
\text { academics do not consider the self- } \\
\text { employed (e.g., a lawyer) to be } \\
\text { entrepreneurs whereas others do. }\end{array}$ \\
\hline & $\begin{array}{l}\text { This is the difference between } \\
\text { someone exploiting an opportunity } \\
\text { and opening a business out of desire } \\
\text { as opposed to being unemployed } \\
\text { and needing to become an } \\
\text { entrepreneur. It is the basis of the } \\
\text { "opportunity" vs. "necessity" } \\
\text { categories popularized by the } \\
\text { Global Entrepreneurship Monitor } \\
\text { (GEM). }\end{array}$ \\
\hline
\end{tabular}

To summarize this section, wakeboarders are not typical entrepreneurs. It would not be surprising to encounter student disagreement as to whether or not riders are entrepreneurs. The instructor should push the students to consider just what makes an entrepreneur an entrepreneur. What kinds of risks do wakeboarders bear? If no wakeboarders are yet household names, does that mean that they are not innovators in the Schumpeterian sense?

\subsection{Sponsorships and corporate branding}

This section should be used as a primer to discuss the role of sponsorship and corporate branding as it relates to both professional athletes that compete in individual sports and how firms can enhance their brands through these types of sponsorships. For wakeboard athletes sponsorship is the primary (and perhaps only) method of generating funds to pay for training and living expenses. The discussion could be started with the question: From a firm's standpoint, what can these athletes bring to the table? This should lead into a discussion on the effectiveness of sports sponsorships as a vehicle to deliver a certain target audience. Another area of interest 
might be the female wakeboarders themselves. In an age where firms have had to implement moral clauses in their sponsorship contracts, perhaps female wakeboarders should use their wholesome image to market both themselves and their sport.

Equally important is a compelling discussion involving the struggles of female wakeboarders to secure sponsorships from major firms that typically spend their advertising dollars in this area. This discussion should involve the problems of securing sponsorships in a sport that (a) does not have a major television deal; and (b) seems to focus its efforts on promoting the men's side of the competition. This conversation could go in numerous directions. Students should be made aware of the household purchasing power that females control. Perhaps the uniqueness of wakeboarding would help the sport recruit firms that would not normally spend their advertising dollars buying sports sponsorships.

Questions for students:

- Examine Dallas Friday's sponsors in Exhibit 2. Look up the websites provided. How would you characterize these sponsors? What market(s)/demographics do they target?

- For these sponsors, what factors might differentiate these products in the minds of consumers? How much of the differentiation is real vs. perceived?

\subsection{Self-Branding and promotion}

Tom Peters, noted management consultant and author, wrote an article entitled "The Brand called You." In the article Peters noted "regardless of age, regardless of position, regardless of the business we happen to be in, all of us need to understand the importance of branding. We are the CEOs of our own companies: To be in business today, our most important job is to be head marketer for the brand called You (FastCompany, 1997, p. 1). Table 2 summarizes these concepts. 
Table 2. Branding concepts

\begin{tabular}{|c|c|l|}
\hline Concept & Originator & \multicolumn{1}{c|}{ Explanation } \\
\hline $\begin{array}{c}\text { Creating your } \\
\text { own brand }\end{array}$ & Brady (2007) & $\begin{array}{l}\text { To brand oneself you need: a distinctive look, a cause, } \\
\text { create a nickname, connect with better brands, and mimic } \\
\text { popular brands. }\end{array}$ \\
\hline $\begin{array}{c}\text { Self-branding and } \\
\text { social media }\end{array}$ & Wetsch (2012) & $\begin{array}{l}\text { In the ever changing world of social media, persons } \\
\text { wishing to market themselves need to follow the Social } \\
\text { Media A-K-I Model (Social Media Awareness, } \\
\text { Knowledge, and Intelligence) }\end{array}$ \\
\hline $\begin{array}{c}\text { The problems } \\
\text { faced by self- } \\
\text { branding }\end{array}$ & Shepherd (2005) & $\begin{array}{l}\text { There are several problems that people face when they } \\
\text { are self-branding: brand conflict, to have one brand or } \\
\text { many, visibility, false promises, personal engineering. }\end{array}$ \\
\hline $\begin{array}{c}\text { Defining personal } \\
\text { branding }\end{array}$ & Morgan (2011) & $\begin{array}{l}\text { Personal branding speaks to one's unique selling and } \\
\text { values within the competitive landscape of all other } \\
\text { brands and is often the source of first impressions for } \\
\text { decision makers. }\end{array}$ \\
\hline $\begin{array}{c}\text { The way to brand } \\
\text { yourself }\end{array}$ & Bence (2008) & $\begin{array}{l}\text { We are already a personal brand; others have brand of } \\
\text { you by the ways they perceive, think, and feel about you; } \\
\text { it is not self-centered; the audience defines it; respond to } \\
\text { emotional and functional needs; be credible; branding is } \\
\text { done 24/7 and 365 days a year; avoid negative behaviors; } \\
\text { do not pretend to be someone else. }\end{array}$ \\
\hline
\end{tabular}

Gorse, Chadwick, and Burton (2010) noted Red Bull has done a good job of combining entrepreneurship, branding, and sponsorship. These authors show how the entrepreneur-oriented energy drink company used select sponsorships to "stand out from the crowd by setting higher prices than competing brands, seeking to reinforce the product's efficacy and status, and establish the company as a premium brand in the eyes of consumers" (p.350). The sponsorships that the company enlisted highlight the entrepreneur-oriented attitude of the company.

Questions for students:

- Describe the various ways female riders might create their own brand. What do you think would be an effective way to self-brand in this industry?

- What characteristics should an individual exhibit in self-branding?

- What can wakeboarding do to revive its fortunes? Does the sport require a new business model, or is it sufficient to revive the old one? 


\section{- How can individual riders help the sport as they help themselves?}

\subsection{Gender issues}

Questions for students:

- To what extent should female riders cooperate with the status quo, and to what extent should they challenge it? How much leverage do the female riders have?

- What responsibilities, if any, do sponsors have regarding the current gender imbalances in the sport of wakeboarding?

These questions stimulate students to consider what is owed: what obligation do the female riders have to those women coming after them? What responsibility do the sponsors bear towards the current generation of female riders? Competing notions of justice from a variety of secular and religious viewpoints will frame this conversation. Students are likely to be lenient with the current women, claiming that they do not have much leverage to change the situation. While it is true these athletes are not powerful compared to the sponsors, seemingly powerless people like Rosa Parks ${ }^{3}$ and Curt Flood ${ }^{4}$ have effected great change by confronting injustice. Sometimes the catalyst for reform is simply taking a stand.

Another common argument for cooperation is that female wakeboarders can accomplish more by working within the system as opposed to rebellion. Improvements in gender equality are likely to be gradual and necessitate some acquiescence to stereotyping and sexualizing the female athletes, at least in the short term. Outright refusal on the part of a majority of women to be objectified might mean that all of the sponsors walk away, since sex sells. On the other hand, there is the chance that such a radical move might also shock the sponsors into heeding the women's demands to be treated more like athletes and less like sex objects.

\footnotetext{
${ }^{3}$ Rosa Parks was an activist in the U.S. civil-rights movement.

${ }^{4}$ Curt Flood was a U.S. Major League Baseball player and a pioneer in labor rights for players.
} 
While it might be easy to cast the sponsors as villains feeding a culture of sexism, students should be pushed to consider other relevant facts. The gap in prize money, for example, may reflect the reality that men are the pioneers in this particular sport, trying more daring moves and thereby providing a higher level of entertainment. The women interviewed for this case wanted to be treated as the serious athletes that they are, but they also acknowledged that they train with men because doing so improves their performance. Sponsors can control how they treat the female riders, but they cannot control the product on the water. Not all of the gender gaps will be remediated through more enlightened policies on the part of the sponsors. Students may suggest that the sponsors support more events for the female wakeboarders, but there should be acknowledgement that this will only happen if the sponsors can profit from them. There is some control here on the part of the sponsors, as their publicity efforts can help to create demand for these events.

\section{Methodology}

We used an exploratory-naturalistic case study methodology to gather and analyze data on how female professional wakeboarders manage their careers. According to Gall, Borg, and Gall (1996), an exploratory data analysis is used to discover "unforeseen or unexpected patterns in data and consequently gain new insights and understanding of natural phenomena" (p. 197). Data were collected from numerous sources. These included: semi-structured personal interviews, observations of participants prior, during, and after interviews (riding sessions, trampoline training, yoga and stretching sessions, and down time on the dock or in the boat after or before training), as well as a review of physical artifacts including media reports and historical records. 
In a naturalistic paradigm, the design emerges from continuous data analysis and is determined by the context (Lincoln \& Guba, 1985; Yin, 2003). The nature of data gathering involves significant human interaction and the rapport established in this context invariably influences the information (Lincoln \& Guba, 1985). It is important to note that the interviewer, who is the first author, was herself a professional rider for three years, which built trust and access to the participants.

\subsection{Data}

The sample consisted of 12 professional wakeboarders, which included six current and six retired female professional riders. Professional status of female athletes was defined by their participation at the professional level in wakeboarding for more than two years and earning an income from their professional status in the sport. All participants were white females over 18 years old with half being 26 or older. The sample was transnational with participants representing the U.S., Europe, and the Asia-Pacific region. Purposive sampling was used to select participants based on their professional status in wakeboarding to ensure that "certain types of individuals or persons displaying certain attributes were included in the study" (Berg, 2001, p. 32). Respondents were interviewed and asked to suggest other potential respondents, thus creating a loop of purposive "snowball" sampling by identifying participants who may have otherwise been overlooked (Lincoln \& Guba, 1985).

Table 3 provides demographic characteristics for the 12 individuals quoted in the case. Due to the small population size and idenfiable characteristics of the participants, neither real names nor pseudonyms were used. All interviews were conducted by the first author in a private, face-to-face setting. ${ }^{5}$ Interviews lasted between 40-90 minutes, were digitally recorded, and

\footnotetext{
${ }^{5}$ The interview questions are available per request. They are too long to be included in the manuscript.
} 
required informed consent prior to each interview. After 12 interviews we felt that no new themes were emerging and that we had reached data saturation (Creswell, 1998).

Table 3: Characteristics of individuals quoted in interviews

\begin{tabular}{|c|c|c|}
\hline Participant & Age & Transition Stage \\
\hline 1 & $26-45$ & Retired Professional \\
\hline 2 & $18-25$ & Retired Professional \\
\hline 3 & $26-45$ & Retired Professional \\
\hline 4 & $26-45$ & Retired Professional \\
\hline 5 & $26-45$ & Retired Professional \\
\hline 6 & $18-25$ & Professional \\
\hline 7 & $18-25$ & Professional \\
\hline 8 & $18-25$ & Retired Professional \\
\hline 9 & $18-25$ & Professional \\
\hline 10 & $18-25$ & Professional \\
\hline 11 & $26-45$ & Professional \\
\hline 12 & $26-45$ & Professional \\
\hline
\end{tabular}

Additionally, field notes were kept in a reflective journal, where the first author documented personal observations and perspectives to ensure transferability (Glense, 2006). Marshall and Rossman (1995) emphasized field notes should be systemic documentation of the interactions with people including their behaviors (body language and tone of voice), social dynamics, surrounding environment (artifacts) and events that occur within the research setting. Field observations are an effective method for the researcher to understand the complexity of social dynamics and how a participant's personal attitudes and bias can impact the research process (Maxwell, 2005).

\subsection{Data Analysis}

Data were analyzed using the constant comparative method designed by Glaser and Strass (1967), which was refined by Lincoln and Guba (1985) and adapted to content analysis. This process consists of unitizing data, categorization, and identifying patterns. Data analyses 
interacted with data collection as each interview guided the collection of information from the next respondent. Each interview ended with an informal member check, which allowed each participant to amend, verify, and extend constructions. Names of individuals and any other information provided that could link a participant to her identity were removed from the analysis in order to maintain the confidentiality of respondents.

During the development of this study, the perceptions and experiences of each participant were crucial in detecting and understanding recurring regularities in the data that emerged as themes, which suggested a shared reality among the athletes. In the initial stage of analysis open codes were identified and then condensed into preliminary categories. Some of these codes included: income source (family, employment inside or outside the wakeboard industry, sponsorship, and/or coaching); sponsorship (requirements for 'employment', contract negotiation, payment); creating a brand name (competitions, media, coaching, and role of sponsors); and demands of being a professional wakeboarder (income, travel, relationships, physical, relationships, alternative identities, and roles). Subsequently, we organized the open codes into axial codes by linking codes together, which aided in discovering the prominent analytic categories (Neuman, 2006). Lastly, selective coding was utilized to connect observations and themes from the different data collection methods and draw forth the quotations presented in the case (Creswell, 1998).

Credibility was established by using triangulation of measures. Member checks with all participants were conducted to further enhance credibility. Transferability was achieved by the first author keeping a reflective journal that provided a contextual narrative that was used to examine the degree of similarity between observations and interviewees' insights (Lincoln \& Guba, 1985). Like all of the women interviewed, the first author was a professional wakeboarder. 
She shared many of the same interests, passions, and experiences. Many of these athletes have known each other for years, where others have only crossed paths briefly; however, all shared a common bond and similar experiences. Although each had her own unique stories and journeys, it is surprising to find the similarities in the stories and personalities. Numerous times during the interview process, the first author could relate to the degree that the subject appeared to be telling the same life story. In order to improve reliability, two of the other authors, who were not involved in data collection and not part of the wakeboarding industry, served as auditors and reviewed all codes, analyses, and interpretations (Erlandson, Harris, Skipper, \& Allen, 1993).

\section{References}

Berg, B. L. (2001). Qualitative Research Methods for the Social Sciences (4 $4^{\text {th }}$ ed.). MA. Allan and Bacon

Creswell, J.W. (1998). Qualitative inquiry and research design: Choosing among 5 traditions. Thousand Oaks, CA: Sage.

Creswell, J.W. \& Miller, D. L. (2000). Determining validity in qualitative inquiry. Theory Into Practice, 39(3), 124-130.

Erlandson, D., Harris, E., Skipper, B., \& Allen, S. (1993). Doing Naturalistic Inquiry. Newbury Park, CA: Sage.

Fast Company (1997). The Brand Called You by Tom Peters. Website accessed February 26, 2013 at http://www.fastcompany.com/28905/brand-called-you

Gall, M.D., Borg, W.R., \& Gall, J.P. (1996). Educational Research, An Introduction. (6 ${ }^{\text {th }}$.Ed.). White Plains, NY: Longman Publishers.

Glaser, G.G., \& Strauss, A. L. (1967). The discovery of grounded theory: Strategies for qualitative research. NY: Aldine Press. 
Glense, C. (2006). Becoming qualitative researches: An Introduction (3 $3^{\text {rd }}$ ed.). New York, NY: Pearson.

Global Entrepreneurship Monitor (GEM) Key Indicators and Definitions. Website accessed June 25, 2012 at http://www.gemconsortium.org/docs/download/414

Gorse, S., Chadwick, S. \& Burton, N. (2010). Entrepreneurship through sports marketing: a case study of Red Bull in sport. Journal of Sponsorship, 3(4), 348-357

Hanan, M. (1980). Life-style marketing. How to position products for premium profits. New York, NY: Amacom.

Knight, F. (1921). Risk, uncertainty, and profit. New York: Augustus Kelly Publishing.

Kirzner, I. (1973). Competition and entrepreneurship. Chicago: University of Chicago Press.

Kirzner, I. (1997). Entrepreneurial discovery and the competitive market process: an Austrian approach. Journal of Economic Literature, 35(1), 60-85.

Kotler, P., \& Lee, N. (2005). Corporate social responsibility doing the most good for your company and your cause. Hoboken, N.J: Wiley.

Lincoln, Y.S., \& Guba, E. (1985). Naturalistic Inquiry. New York, NY: Sage.

Marshall, C. \& Rossman, G.B. (1995). Designing Qualitative Research. London, UK: Sage.

Maxwell, J.A. (2005). Qualitative research design. An interactive approach ( $2^{\text {nd }}$ ed.). Thousand Oaks, CA: Sage.

Neuman, W.L. (2006) Social research methods: Qualitative and quantitative approaches, 6th ed., Boston: Pearson Education.

Schumpeter, J.A. (1934). The theory of economic development. Cambridge: Harvard University Press.

Schumpeter, J.A. (1942). Capitalism, socialism, and democracy. New York: Harper Brothers. 
Shane, S. (2003). A general theory of entrepreneurship. Northampton: Edward Elgar Press.

Shane, S., \& Venkataraman, S. (2000). The promise of entrepreneurship as a field of research. Academy of Management Review, 26(1), 13-17.

Storey, D. (1994). Understanding the small business sector. London: Routledge Press.

Troilo, M. (2010). The role of trust for new SME creation: Differences in motivations and opportunities. International Journal of Entrepreneurship and Innovation, 11(2), 129139.

Venkataram, S. (1997). The distinctive domain of entrepreneurship research: An editor's perspective. In J. Katz \& R. Brockhaus (Eds.), Advances in Entrepreneurship, Firm Emergence and Growth, 3, (pp. 119-138). Greenwich, CT: JAI Press.

Yin, R.K. (2003). Applications of Case Study Research ( $2^{\text {nd }}$ ed.). Thousand Oaks, CA: Sage. 